\title{
KARJALAISET JOIUT
}

Joiku tunnetaan ehkä parhaiten saamelaisten kansanrunouden lajina. Mutta joikuja löytyy myös karjalaisesta perinteestä, nimittäin Vienan Karjalasta, jossa joikuperinne on esiintynyt hyvin suppealla alueella Tuoppajärven, Pääjärven, Koutajärven sekä Ylä- ja Keski-Kuittijärven ympäristössä ja osittain etelämpänäkin, Kiitehenjärven kylissä. Joikuja on siis laulettu vain Vienan Karjalan länsiosassa, sen sijaan itäisellä alueella niitä ei ole tunnettu.

Sana "joiku" on perinteentuntijoille tuttu, mutta tavallisemmin käytetään sen verbimuotoa "joikuo" tai "joijutah" jotakuta. Verbi "joikua" merkitsee yleensä kovaa, kauas kaikuvaa, sointuvaa ääntä. Sillä tarkoitetaan myös metallista sointia, lehmän ammuntaa, kirkon kellon kaikua. Se esiintyy eeppisessä runoudessa:

Nenä /venehen/ joikuu joutsenena,

Perä karjuu kuarnehena.

Pyyrimet pyynä vihelti...

Edelleen:

Joet joikui, järvet järkkyi,

Vuoret vaskiset vavahti...

Näin ollen kansnrunoudessa sen synonyymeja ovat "karjuo", "huutaa", 
"viheltää" jne.

Ensimmäiset joikumuistiinpanot Vuokkiniemellä, Pistojärvellä ja Uhtualla teki suomalainen tutkija I. Fr. Cajan vuosina 1836 ja 1837-39. Muutamia joikuja pani muistiin Elias Lönnrot 1837-39 Kontokissa ja D.E.D.Europaeus 1845-46 Kiestingin kylissä sekä Akonlahdella ja Kontokissa. Kahdesta viimeksi mainitusta kylästä ei myöhempiä muistiinpanoja olekaan saatu. Myös A. Boreniuksen ja S. Paulaharjun kokoelmissa on muutamia joikutekstejä. Joikujen suurkerääjä ja samalla niiden tutkija oli etevä kansanrunouden tallentaja A. O. Väisänen. V. 1915 hän teki pitkän matkan Vienan Karjalaan kulkien pohjoisimmasta Kn'äžöin kylästä Vuokkiniemelle, jolloin hän kävi 21 kylässä ja sai joikuja 13 kylästä (Ks. Väisänen 1915). Suomalaisten tutkijain kokoama aineisto on tallella Suomalaisen Kirjallisuuden Seuran Kansanrunousarkistossa, jossa joikujen yhteismäärä on 138, mukaan luettuina 1-2 säkeisetkin tekstit.

Petroskoissa Kielen, kirjallisuuden ja historian tutkimuslaitoksen käsikirjoitus- ja nauhoitearkistoissa joikuja ja joikumuistiinpanoja löytyy likipitäen 30 kylästä. Ensimmäiset 8 muistiinpanoa on tehnyt Risto Bogdanov Kiestingissä v. 1928 ja viimeiset muistiinpanot Nina Lavonen Kiestingin/Oulangan Niskan kylässä v. 1983.

1930 ja -50-luvuilla joikuja olisi varmaankin voinut saada enemmän, mutta tuolloin ja sitä aiemminkin etsittiin ennen muuta kalevalanmittaista runoutta ja satuja ja joiut ja myös itkuvirret jäivät syrjään. 1960-luvulta alkaen on joikuja nauhoittanut jonkin verran Sandra Stepanova Kiestingin ja Uhtuan kylissä. Taitava niin joikujana, kuin muunkin perinteen tuntijana oli tuolloin Moarie Malikina Pistojärven Hämehestä - kaikkiaan häneltä nauhoittetiin 7 joikua. Myöhemmin joikujen taitajia on ollut vaikea löytää. Yllätyksenä olivat Pekka Zaikovin v. 1972 Matr'ona Vdovinalta nauhoittamat 6 joikua. Vielä v. 1982 sai Nina Lavonen Moarie Arhipovalta 4 joikua.

Vuodesta 1975 alkaen on Nina Lavonen tutkinut Kiestingin seudun kansanrunoutta ja käynyt useita kertoja keruumatkoilla Kiestingin ja Oulangan kylissä. Tuohon aikaan ei joikuja enää laulettu jokapäiväisissä oloissa, mutta muistitietoa joikumisesta oli vielä säilynyt. Yritimme tallentaa joikujen laulamista koskevat pienimmätkin yksityiskohdat. Missä ja milloin joiuttiin? Kuka esiintyi joikujana? Ketä joiuttiin? Kun päästiin keskusteluun, niin puhe joiuista alkoi tavallisesti seuraavasti: "Vet iče olen joikun. Kun marjašša olin, ni yhtä akkua joijuin, kun poika oli lähöššä armeijah... Ni en maha nyt, en muissa"... (Fon, 2220/6). ${ }^{1}$

\footnotetext{
${ }^{1}$ Fon = fonetika, Petroskoin Kielen, kirjallisuuden ja historian instituuttien äänitearkisto
} 
Tärkein joikujen aihepiiri onkin poikien tai poikamiesten seikkailut rakkausasiat, morsiamen valitseminen, ajanvietto, tavat ym. Mutta avioliiton solmimisen jälkeen (akottumini) miehiä ei enää joiuttu: "Ka poikie vain joijuttih. Ken akottu, ni sitä enämpyä ei joijuttu"(Fon. 1697/3). "Siitä kun ottau naisen - vs'o /kaikki/"(Fon. 2211/3). Niinpä joiuissa poikien naimattomana olon aikaa sanottiinkin "joijunta-ajaksi", se oli siis aika, jolloin nuorta miestä oli lupa joikua.

Mutta jos mies jäi leskeksi tai otti avioeron, häntä oli taas lupa joikua. Darja Nikonova (Kostovaaran kylästä) kertoi, että avioeron jälkeen miestä joiuissa nimitettiin "puolipojaksi".

Kun kuvattiin, "paneteltih" poikamiehen elämäntapoja ja seikkailuja, sen yhteydessä voitiin luonnehtia myös pojan vanhempia - äitiä ja isää, joskus myös neitoa, jonka kanssa poika seurusteli tai jota hän kosi. Usein joikujen sisältö lähenteli satiiria ja sille oli ominaista myös huumori.

Kysymys siitä, joiuttiinko häissä, on jossain määrin epäselvä, mutta haastateltaviemme kertomuksista päätellen sulhaselle joiuttiin sulhasen kotona silloin, kun hän oli lähdössä kosimaan sekä morsianta hakemaan. Joiuttiin myös nuoren parin saavuttua sulhasen kotiin, juuri heitä vastaan otettaessa. Sulhasen puolesta ja sulhasen kotona joikuminen siis ikään kuin korvasivat äänelläitkun. Seuraavat tiedot vahvistavat tämän. Ustinja Tokarevan (Vartiolammen kylästä) mielestä häissä "ei joijuttu, vain itettih. Ennen sitä joijuttih ta... vieläi jäleštä... mimmoni taloh /siis, sulhasen taloon, perheeseen/ morsien tuotih". (Fon. 3217/1). Puhe on häämenoista morsiamen perheessä, jolloin itkettiin. "Ennen sitä" ja "vieläi jälkeh" tarkoittaa juuri sulhasen perheen häärituaalia. Miihkali Isakov totesi: "Häissä joijuttih tai iänellä itettih... Joijuttih šulhasen koissa, sielä iänellä ei itetty... Tumčašša hiät piettih, tuotih, moršien taloh. Yksi akka joikuu, jotta... 'ooo ooo tämä kun on kaunis kanani tuotu šuuren kalajärven rannašta... joo ooo ne... Tämä tulou kapperaini iessä kalleheh hyväseh, ei ole šuurempi töih... Tämä on šorša tuotu suuren joven suusta. Heän on šukkelaini ... Mieleštä kun on mänty kaikki šanat... En mie malta enämpi'"(Fon. 3217/23).

Seuraavassa tarkastellaan joikujen aihepiirejä (tutkimuslaitoksemme aineiston perusteella). Perusaiheena on, kuten edeltä jo ilmeni, nuoren miehen naimapuuhat ja ajanvietto.

1.1. Seurustelu tyttöjen/naisten kanssa. Joiuissa tarkastellaan tavallisesti poikamiehen tunne- tai rakkauselämää, jopa hänen seksuaalista käyttäytymistään; arvostellaan poikaa sekä samalla hänen valitsemaansa neitoa. Niissä voidaan moittia tai nuhdella nuorta miestä, jos hän käyttäytyy ihmisten mielestä väärin, viettää öitä naisten parissa - "kulkou koppaloijen 
koikkasijoilla" (sängyissä), "lepyälöy lehvomien leposijoilla".

1.2 Poika kosii tyttöä ja saa rukkaset, "aparat". Sitä pidettiin häpeänä, ja se loukkasi nuoren miehen kunniaa (A.29/3). ${ }^{2}$

1.3 Joikuja luonnehtii tulevaa tai mahdollista avioparia, sekä poikaa että morsianta, heidän ulkomuotoaan (kaunis/ruma), luonteenpiirteitään (hyväntahtoinen/tyly ym.), suhdetta työhön ym. seikkoja: "Onpaš morsian kaunis kanani kaijan rannan." Joskus saatetaan morkata, jopa loukatakin morsianta. Niinpä eräässä Uhtualla esitetyssä joiussa sanotaan:

Tuotihpa korvesta kontie,

karhu karulta mualta,

vejettih venkistä vetehini... (A. 26/5).

1.4. Samalla luonnehditaan nuoren miehen vanhempia, useimmiten äitiä, sillä ihmisiä tuntuvat huolestuttavan tulevan anopin ja miniän väliset suhteet: osaako nuorikko tehdä töitä ja käyttäytyä anopin mielen mukaan, osaako hän sopeutua talon tapoihin jne. Tämän yhteydessä taas luonnehditaan sekä neitoa että pojan äitiä: "Voipiko še ottua kantajaiseh vaštah kanasen kauneheh luatuh; ... ei ole šoršani myöten sorttie šuorijaiseh ..." "Eikö tulis vierialli /morsian/ arvuo myöten ankarašiamen aikajaisen /pojan äidin/?" (Fon, 1701/10) Joiku tuomitsee laiskoja, ylpeitä, epäsiistejä. "Ket oltin hyvät, hyvällä joijuttih, ket pahat, niitä vieläi loukattih" (Fon 3217/1) tai "Vet on karmakka kauniveren kantajaini (pojan äiti)" tai "Ta rupieu šoimual'omah šoršaista somavertä" (Fon. 268/1).

Vaikka joikujen peruskohteena onkin poikamies, niistä löytyy paikkansa myös hänen morsiamelleen ja vanhemmilleen, joskus muillekin sukulaisille.

1.5. Jos jompikumpi, sulhanen tai morsian, oli huomattavasti vanhempi, saattoi sekin olla joikumisen aiheena. Joikumisen arvoisia saattoivat olla myös eräät muut tapahtumat.

2.1. Avioliiton ohella tärkeä tapahtuma nuoren miehen elämässä oli asepalvelukseen astuminen ja semminkin sotareissu. Kiestingin seudulla saattoi tuolloin kuulla sekä äänelläitkua että joiuntaa. Joiuttiin myös, kun mies palasi sotapalveluksesta tai saapui lomalle. V. 1972 Kn'äžöissä Moarie Koikeroiva (synt. Heinäjärvellä) esitti meille pitkän sotilasaiheisen joiun. Hän kysyi pojan äidiltä: "Oletko olovan suurissa kaiholoissa, kun lähtöy kantamaiseš kaihoilla kamantateillä, -- Otetah pilvišuven pitillä prijomateilla."

Useita tämänaiheisia joikuja on A. O. Väisäsen muistiinpanoissa - olihan menossa ensimmäinen maailmansota ja aihe oli siis hyvin ajankohtai-

${ }^{2} \mathrm{~A}=$ Petroskoin kielen, kirjallisuuden ja historian instituutin arkisto 
nen. Ruvan kylässä Väisänen sattui olemaan siihen aikaan kun poikia saatettiin Koudan arvannostoon. Sotateille lähtevää poikaansa saattoi äiti itkuvirsin ja kylän naiset joikumalla. Nuo joiut olivat hyvin surumielisiä tai jopa murheellisia, kun nuoret miehet vietiin sotateille "ruunun rautoja /aseita/ kantamah".

2.2. Myöhempään syntyneinä voi pitää joikuja opinteille lähtevälle pojalle. Juuri sellaisen pani muistiin Risto Bogdanov v. 1928 Kiestingissä. Olihan opiskelemaan meno tuolloin vielä harvinainen tapahtuma.

2.3. Aikamme tunnusmerkkinä voi pitää joikuja poikamiesten (yleensä miesten) juoppoudesta. "Votkan" nauttimisongelma on kipeä ja se on huolestuttanut naisia. Ei voi olla välinpitämättömänä, kun "korkievartiset" (soreat miehet) ovat "kovuan vetelijät vierojen maijen vinkeroja viinavetysie". Usein se on syynä siihen, että poika ei saa vaimoa, pahoinpitelee äitiänsä jne.: "ei voi heittyä helietä aikua, kun aina viuhahtelou viinapäissä. Ka vet ni veršojaistah vihual'ou niissä viinapäissä, ni kovuan äijän šuurissa šuusanoissa šuorijaisellah šuorittau..." Sulhasen isääkin luonnehditaan vastaavasti, kun hän "vielä kačcou ni korliškan (pullonsuu) syvyyttä... Kuulu hyväseh /isä/ kuvua l'eutuu korliškan pohjalla." (Fon. 1031/2).

2.4. On myös tilapäisjoikuja. Niissä saatetaan kommentoida erilaisia asioita, kylätapahtumia, tapaamisia.

2.5. Erikoisen ryhmän muodostavat joiut, joita on esitetty kansanrunouden kerääjille - nuorille miehille. Niitä on runsaasti A. O. Väisäsen kokoelmissa sekä Risto Bogdanovin muistiiinpanoissa Kiestingistä.

Väisänen oli nuori naimaton ylioppilas ja hänelle hyvinkin sopi joikua: "Suori varsi on Suomen rajalta, Kierävarsi on kieleltä(?) Kirkkomaien laulun keryennässä"... Joikujanaiset ottivat huomioon hänen kameransa, fonografinsa, jopa kultahampaansakin: "Helie hammas on Helmimarjalla heikkojen maien, Kultahammas on Kukkamarjalla kurjien maien kulman alla..."

Emäntiä ei miellyttänyt se, että Väisänen tupakoi, sillä vielä vuosisatamme alussa Oulangassa, Kiestingissä ja muissakin vienalaisissa karjalaiskylissä oli tupakointi tuvassa kielletty, sillä vanhauskoisuus, jolla vielä silloin oli vahva pohja, kielsi tupakoinnin ja viinanjuonnan. Ei saanut missään tapauksessa tupakoida tuvassa. Tupakointia joiuttiin seuraavaan tapaan:

Tuhmien maien tupakkisavut, kaihojen maien karkien savut, inhujen maien ilkiet savut, vierojen maien vihaset savut, kurjien maien koppasavut... 
Myöhemmin tämä aihe ei enää huolestuttanut joikujia, sillä tupakoiminen tuli yleiseksi tavaksi ja sitä ei enää pidetty niin suurena paheena. Kuitenkin yhdessä joiussa, jonka esitti Ol'ona Pivojeva v. 1956, arvostellaan sulhasta, ettei hänestä tulisi "tupšualija... tuurojen maijen tupakkišavujen".

2.6. On myös olemassa joukko niiin sanottuja yhteiskunnallisiaiheisia joikuja. Ne on pantu muistiin 40-luvulla Uhtualla, jolloin oli tapana sepittää aiheiltaan uusia, siis uutta elämää, Neuvostovaltaa ylistäviä runoja, satuja, lauluja. Joukosta löytyy myös muutama joiku. Uljana Hoikka kuvaa sodan uhkaa Neuvostoliittoa vastaan: "Vain kuin uhkuau ulkolaini, ta pakkautuu paholaini, šortamah šovettivaltua, ta eštämäh Neuvošton elämyä." (Fon. 46/5).

2.7. Vielä voi erottaa lyyrilliset joiut, joita tavataan vain Kuittijärven ympäristössä - Uhtualla, Vuokkiniemellä ja Akonlahdella. Runoasultaan ne ovat kalevalamittaisia, kuten yleensä joiut tällä seudulla, mutta ne eroavat eeppisistä lauluista melodiansa puolesta. Sitä paitsi niissä esiintyy omalaatuinen laveasointinen refrengi. Sisällöltään ne muistuttavat Kanteletar-aiheista lyriikkaa, ilmaisten naisen yksinäisyyttä, erosta johtuvaa surua, rakkauden kaipuuta. Esimerkkinä voi olla Maura Hotejevan esittämä joiku:

Missä ollou kurjasen kumppali,

marjasen makuuvel'l'i,

tuššasen tuutuvel'l'i?

En voi marjani malttua,

ollouko ilmoilla etelän

vain šuuluilla Šuomen niemen?

Olisko čirkun šiivet,

eli linnun lentimet,

eli vetimet vesilinnun,

lentäisin koittiessa kor'an,

mänisin ilmoilla etelän...

(A. 12/105).

Jotkut joikuaiheet ovat unohtuneet nopeammin, jotkut säilyivät kauemmin. Kun kesällä v. 1990 kysyimme Mat'ro Sidorovalta (Kokkosalmesta), mihin ennen kaikkea pojassa huomiota, kun häntä aiottiin joikua, niin hän vastasi: "Viinua /jos/ joi, torasi humalassa eli tyttöjä narrasi, ei ottan..." (Fon. 3219/3).

Joiun melodian tunnusmerkki on omalaatuinen refrengi. Refrengin esittäminen oli joiuttaessa tärkein ja samalla vaikein tehtävä. Joiun tehon voi sanoa olevan juuri refrengissä. Tunnettu runonlaulaja Tatjana Perttunen onkin hyvin osuvasti huomauttanut: "Jokahini joukuo šuattau, vain ei šuata luikahuija". Refrengin laulamista kutsutaan nimellä joijutus, hehetys, 
luikahus. Jokainen esittäjä käyttää refrengiä omalla tavallaan. Toisilla se toistuu jokaisen säkeen jäljessä, toisilla taas jonkin tietyn säeryhmän jäljessä. Sillä ei ole tarkkaa muotoa, vaan se riippuu joikujan tahdosta ja taidosta, lahjakkuudesta.

Joikujen "klassillinen" esityspaikka on ollut järven ulappa. Soutaessaan naiset saattoivat joikua huvikseen koko pitkän matkan. Vienankarjalainen nainen airot kädessä /soutamalla/ menee kalaan, heinäntekoon, marjaan, vastoja hakemaan... Perinteentuntijat korostavatkin usein, että joiuttiin "hyvällä kaunehella šiällä, konša on tyyni... Kaikki šiitä kylä kuulou šen, järvellä ta rannašša, tai jovella..."

Toinen yleinen joikumistilaisuus oli keväinen "pirtin pesu" elikkä "suuri pesu", "konša šuurella pešulla pirttijä peštih". Se tapahtui tavallisesti ennen pääsiäistä. Noin 5-6 naista naapuristosta kerääntyi yhteen taloon "pirtin pesulle" ja sitten vuoronperään pestiin jokaisen pirtti. Laulu kaikui ja sointui, ja aika kului huomaamatta.

Vaikka joikujen aiheet ovatkin hyvin erilaisia, itse laulajat määrittelevät niitä ilolauluiksi: "Joiku še on iloni, a iänelläitku še on šuruni, ero on šuuri"... (Fon. 3217/22). Joikumalla "saivatkin naiset nauramista, ihmiset imehtimistä".

Mutta aina ei joiku ollut sisällöltään iloinen. Tämä koskee ennen muuta joikuja sotaan ja asepalvelukseen lähtevälle nuorelle miehelle.

Tavallisesti joikujina esiintyivät iäkkäät naiset - akat, ja he puolestaan olivat kuulleet ja oppineet joikuperinteen "muamolta", "ämmöltä", "puapolta" (kätilö), "tädiltä". Nuoret eivät joikuneet, se ei kuulunut tapoihin: "Nuoret ei miun muistih joijuttu", muistelee useampi kertojistamme.

Vaikka suurin osa joikujista on ollut naishenkilöitä, joskus joikujina esiintyivät miehetkin. Laitasalmen kylässä oli hyvin taitava ja kuuluisa joikuja Miitreilän Il'l'a. A. O. Väisänen tapasi hänet v. 1915 kun tämä oli 62-vuotias. Vielä 1980-luvulla muistettiin Miitreilän Il'l'aa. Moarie Pöttöjevä Laitasalmelta kertoi: "Miän kyläššä oli ukko semmoni, Il'l'akši kučuttih, nin hän joiku tai iänellä itki, tai itetti niitä miehellä mänijie; parta šuuri šemmoni. Nakrettih aina, jotta tuaš Il'l'a joikuu kajahuttau." (Fon. 2605/la). Moarie Arhipova Niskan kylästä, joka oli lapsena tuotu Kolvitsaan, lähelle Kantalahtea, muisteli: "Miula muamo mainičči, hänen t'iätä... illalla kun käyväh verkkoja laškomah, niin še ukko niise (joikui). Siitä joijutah täyttä keruo /kurkkua/, ukko ta akka molen joijutah. Ukko kaikičči akkah kera yheššä joijuttih." (Fon. 1697/3). Vuonna 1982 meille joikui Miihkali Isakov ja hän osasi myös itkeä äänellä. Ja vielä myöhemmin, vuonna 1990, hän totesi että "joijuttih ukot, erähät ukot joijuttih". Mutta silloin, 88-vuotiaana, hän ei enää voinut itse joikua. Hän muisteli, miten 
joijuttiin - joikujana oli mies - nuorelle parille sulhasen kotona: "Yksi poika oli Nisassa, akottu. Hiän oli tyttären suatu. /siis avioton lapsi/. Iče salvo pirtin. Läksi šulhasiksi Ruvah, toi morsiemen. Siitä ukko sielä joikuu, jotta 'toit sie šoršasen Šuomen šulkkuvuatteissa, a et ole näitä šeinäpuolie šilitellyn. Šorša puuttu Šuomen sulkkuvuatteissa, šeinähiršie kun olet pahoin šilitellyn..."'

Kenttätyön yhteydessä on ilmennyt, että joikua saattoi esittää kerrallaan kaksi taikka useampikin joikuja. Vaikka nauhoituksissamme ei sellaisia muistiinpanoja olekaan, monet muistelevat, että "joijuttih kahen, joijuttih kolmen". Nasto Saloniemi (Tuhkina) kertoi, että nuorempana hän joikui erään naispuolisen naapurinsa kanssa. Samaa ovat kertoneet myös Niskan, Pistojärven, Suurisaaren, Vartiolammen entiset asukkaat. Tosin taas Fedosja Nikonova (Katošlammen kylä), joka itse hyvä joikuja ja äänellä itkijä, väitti, että joiuttiin vain yksin.

Kysymys oli kiinnostanut myös A. O. Väisästä. Hän kirjoittaa, että joikuja laulettiin ennen joukolla. Vuonna 1922 hän oli jopa nauhoittanut kahden henkilön esittämän joiun. Havaintojensa perusteella Väisänen huomauttaa, että toinen laulajista oli vain "melodian kannattajana" /hyräili vain melodiaa/. Tämän johtopäätöksen vahvistaa Fedosja Pavlova (Suuri saari): "Joijuttih kahen - yksi šanou šanat, toini vetäy iänellä."Kysymys joikujen ja myös itkuvirsien ryhmäesityksestä kiinnittää huomiota juuri sen vuoksi, että näiden kummankin esittämis- tai luomisprosessi on omaperäistä improvisaatiota, vaikka niiden aihepiiri, motiivit, vieläpä kieliasukin ovat tiukasti perinteen määräämiä. Siksi kahden ja useamman henkilön osallistuminen luomisprosessiin vaatii esittäjiltä hyvää yhteisymmärrystä. A.O.Väisäsen käsitys onkin varmasti paikkansa pitävä.

Joikujen teksti ei ole kiinteä. Samalta esittäjältä ei saa kahta täysin identtistä, samanaiheista joikutekstiä. Tekstissä on aina joitakin eroja sekä sisällössä että kielenkäytössä. Tämä johtuu juuri joiun improvisaation omaisuudesta, mikä erottaa sekä joiun että itkuvirren muista kansanrunouden lajeista.

Vaikka joiku onkin improvisaatiota, se aloitetaan usein tietynlaisella alkulauseella:

1. Alanko mie, kuomasen, joikuo johuuttoa...

2. Rupiemma joikuo jo laulamah, alta kulmien kulahuttamah...

3. Anna soittelemma... /Suojuslahen Okun suorimoa/...

4. Kovorimma kaksi-kolmi sanua...

Loppu saattaa olla esim. seuraavanlainen:

1. Jo loppu joiun aika, /jo lankes'laulun aika...

2. Nyt heitämmä heläytyksen... 
Useimmiten loppu tulee yhtäkkiä:

1. Vs'o /kaikki/, en voi enämpyä...

2. Välttäy, vel'l'en...

3. Emmä nyt huoli enämpi!

4. Enkä voi enämpi, niin iäneni kähistyy...

5. En tiijä, vain piätä siun kera kivistäy tänä päivänä...

Joikujen kieliasu, erikoisesti niiden kuvakieli, poikkeaa suuresti muista kansanrunouden lajeista ja lähentelee itkuvirsien metaforakieltä. Ennen kaikkea tämä koskee tapaa ilmaista henkilöiden nimiä. Joiuissa sen enempää kuin itkuvirsissäkään ei käytetä suoranaisia sukulaistermejä, sellaisia kuin poika/poikamies, tytär, äiti, isä, vaan ne ilmaistaan vastaavilla metaforisilla henkilönnimityksillä, kierto- ja salanimillä. Joikujen käytössä onkin runsaasti erikoisia kiertoilmaisuja, joiden avulla ilmaistaan paitsi sukulaistermejä myös muita ilmiöitä ja käsitteitä. Esimerkkinä tästä ovat itse joiun, joikulaulun nimitykset, joita ovat "kajattelusanat", "kelekettelyšanat", "viršielyšanat", "kelketykset".

Kiestingin ja Pistojärven runomitta ja säerakenne (tai runomitan puuttuminen) on itkuvirsiperinteen tapaan hyvin omalaatuista. Kuittijärveä ympäröivien kylien joikurunous taas noudattaa kalevalanmittaista runosäettä:

Olisko šuuššani sulua voita,

elikkä kielellä kešävoita...

On sanottava, että Kiestingin ja Pistojärven joikurunot vaikuttavat kehittyneemmältä ja niiden aihepiiri on laajemmalta ja monipuolisemmalta.

Joikujen pääosassa, siis kohteena, on nuori mies. Hänestä käytetään kymmeniä kierteleviä, tarkoin valittuja nimityksiä. Niissä kuvastuu poikamiehen olemus. Tavallisesti tällainen henkilönnimitys on kaksiosainen ja se koostuu epiteetistä (voidaan ilmaista nimi- tai laatusanalla) ja varsinaisesta vastineesta, siis metaforisen nimitysvastineen perussanasta. Yleisimmin käytettyjä pääsanoja ovat "varsi", "varto" /vartalo/; käytetään myös substantiiveja "kasvo" (verbistä kasvaa, siis pituus, korkeus), "muoto", "tukka", "veri", "kulma" ja eräitä muita. Kaikilla näillä ilmaisukeinoilla on omat, joskus myös yhteiset määritteensä. Muutamia esimerkkejä pojan nimityksistä ovat seuraavat:

$\begin{array}{llll}\text { aisavarši } & \text { šuojakašvo } & \text { kaunis muoto } & \text { vannehkulma } \\ \text { kaisl'avarši } & \text { pienikašvo } & \text { komie muoto } & \text { kullankorši } \\ \text { virpivarši } & \text { vajua kašvo } & \text { kuvaveri } & \text { kešämarja } \\ \text { šorie varši } & \text { kokkotukka } & \text { valoveri } & \\ \text { vihanta varši } & \text { sulkkutukka } & \text { šomaveri } & \\ \text { valkie varši... } & & & \end{array}$


Tämänkaltaisia nimityksiä löytyy yli 40. Joskus, tosin harvemmin, käytetään laajempia sanayhdistelmiä kuten seuraavia:

kotikuvan korkuoja varši;

olovan šuven oimun ainuo;

päivän heittäytyjän ainuo ym.

Jos nuori mies on orpo, hänestä käytetään nimitystä "helvojatoin", "kuvuajatoin", "veršojatoin", siis käytetään äidin metaforavastineen - helvoja, kuvuaja, versoja ym. - kielteistä muotoa. Melkein kaikki nimitykset kohdistuvat nuoren miehen ulkomuotoon: hän on kaunis, solakka, voimakas, terve.

Häitä edeltävissä ja häiden yhteydessä esitetyissä joiuissa puhutaan myös morsiamesta/neidosta. Hän on "allini" (alli - sorsalaji, Glangula Hyemalis), "kana", "koppala", "šorša" "vikli" monine kauniine epiteetteineen; myös "kukka", "maima"; "šormuškäsi", "kaššapiä" ym. Näin ollen syntyy hyvin runollinen, lempeä kuva morsiamen olemuksesta. Hän on kaunis, nöyrä, hento, hyväntahtoinen, työteliäs ja kaikin puolin sopiva aviopuoliso.

Äidin ja isän nimitysvastineet ovat samoja kuin itkuvirsissäkin. Äiti on "aikojaini", "kantajaini", "mainojaini", "palvojaini", "tuuvittajaini", "viihyttäjäini"; isä taas "hyväseni" monine määritteineen, kuten "kuulu", "or'hie", "valkie", "viekas".

Joikujaa ilmaistaessa, siis joikujan minä-käsitteen vastineista suurin osa on erilaisia lintumetaforia: "kanat katovaikäset"; "kiurut kirpuovaikäset"; "laklot lankieväijät"; "sotkani sortuvaikä"; "viklot vieroväijät"; "koppalat kuolovaiset". Joskus yksinkertaisemmin - "vieroväikäset", "vaipuva ikäpuoli". Näistä nimityksistä päätellen joikujina esiintyvät ikänaiset. Miesten minä-vastineita meillä ei toistaiseksi ole, vaikka miehetkin ovat joikuneet.

Pojan tai nuoren miehen elämä, hänen elinkaarensa, elinaikansa on saanut joiussa omat nimityksensä, joita on kymmeniä. Kaikissa niissä toistuu substantiivi "aika", joka on saanut mitä erilaisimpia epiteettejä: "ašeuvunta-", "joijunta-", "kul’ainta" /seurustelu, kävely-/, "herruuš";, "kisa-", "vierišija-", "sokola-aika". Näistä kaksi viimeistä vaatinevat selitystä. "Vierišija-aika" tarkoittaa poikamiehen "yöseikkailuja", naisten yövieraina käymistä, kun hän "kulkou koppaloijen koikkašijoilla"; "lepyälöy lepošijoilla". "Sokola-aika" /sokol - ven. "kokko"/ taas merkitsee naimattoman miehen elämää, naimatonta nuorta miestä, sekä venäläisessä että karjalaisessa kansanrunoudessa, esimerkiksi häälauluissa.

Kun hääaiheisissa joiuissa ilmaistaan huolenpitoa, sitä minkälaiset suhteet syntyvät anopin ja morsiamen välillä ja sitä onko tuleva morsian/miniä mieluinen sulhasen äidille, käytetään myös määrättyä sanontaa, 
sanaklišeetä. Morsian ehkä on tai ei ole: "arvuo myöten /aikojaisellah/", siis pojan äidille"; "henkyttä myöten", "kašvuo myöten" ja jopa "kielyttä myöten", myös -"kohtua", "mallie", "sorttie", "tuntuo", "vaččua" ym. myöten sekä "arvon mukah", "iman/älyn/jälkeh/" ym. Useimmiten pohditaan, osaisiko nuorikko suorittaa koti- ja talousaskareet eli "olkatyöt", "ankehet työt", "sujottatyöt" -arvuo, sorttie ym. anopin mieliksi. Taloonhan tuotiin nuorikon muodossa ennen kaikkea työntekijä.

Kuten jo näistä esimerkeistä ilmenee, joikujen kuvakieli on hyvin rikasta, ilmeikästä. Yhden artikkelin puitteissa ei ole mahdollista kertoa kaikista kielellisistä erikoispiirteistä. Muutama esimerkki on vielä tarpeen eräistä, huomionarvoisista käsitteistä. Mielenkiintoisilta kuulostavat joiuissa käytetyt niin sanotut "paikannimitykset", siis paikkaa merkitsevät ilmaisukeinot, joita olemme poimineet lähes 70 erilaista. Ne ovat yleensä yhdyssanoja tai erilaisia sanayhdistelmiä. Kantasanoina esiintyvät -nimi, "salmi-", "ranta", "-järvi", "-meri", "-joki"; kantasanoina saattavat olla myös ilmansuunnat "suvi", "-pohjani/pohjoni"; maiseman erikoisuudet kuten "-lošo", "-luoma", "-čokka" (kolkka) ym.

Tämäntapaiset kantasanat määritteineen muodostavat mitä ihmeellisimpiä kuvainnollisia "paikannimityksiä" - Kaivoniemi, Kotiniemi, Šuovaniemi, Viehkaniemi; Kotišalmi, Šulkušalmi, Ušvašalmi, Virtašalmi; Kaitaranta, Ojaranta, Vihuriranta; Karijärvi, Ualtojärvi; Vinkameri; Virtajoki Koitašuvi; Pilvišuvi, Viimašuvi, Kirkaššuvi, Šumpiešuvi; Kal'l'akka pohjani, Vieraš pohjani; Kaššeriäty; Kuuši lošo; Varpaluoma; Hiekkačokka; Virrankorva ja monet muut. Selvä on, että nämä "paikannimet" ovat spontaanisti muodostettuja ja niitä käytetään vain joikulauluissa. Niiden välityksellä myös luonnehditaan joiuttavaa henkilöä, poikamiestä. Usein niillä vihjataan, kenestä on puhe, kun joiuissa ei tavallisesti mainita nimiä. Samalla ne ilmentävät kaunista ja tuttua Karjalan luontoa järvineen ja jokineen.

Joiuissa on sellaisiakin venäläisiä lainasanoja, joita ei esiinny jokapäiväisessä puhekielessä. Niiden funktio on sama kuin toistenkin kiertoilmaisujen eli välttää nimittämästä ilmiötä, henkilöä, käsitettä suoraan, siis piilokielen ylläpitäminen. Puhekielessä niillä ovat omat karjalaiset vastineensa. Muutama esimerkki valaisee tätä: kat't'ie (катить) - tässä tapauksessa "ajaa, matkustaa, saapua"; komkka (комок) - möhkäle, tukku; korova (корова) - lehmä; kovorie (говорить) - puhua, kertoa, umnoi (умный) älykäs, viisas; viečora (вечер) - ilta.

Joikujen sisältöä on vaikea ymmärtää. Siihen on syynä ensinnäkin joikujen piilokieli ja moninaiset kiertoilmaisut. Toiseksi syynä on se, että joiuissa on aina puhe konkreettisesta henkilöstä ja hänen nykyisestä elämäs- 
tään, elinympäristöstään, tavoistaan ja monista muista aivan konkreettisista seikoista; joiun esityshetkenä kyläyhteisö tuntee ja tietää joiuttavan henkilön elämänvaiheet ja elinolot. Mutta myöhemmän ajan lukija/kuulija, joka ei ole tietoinen niistä oloista ja kaikenlaisista pikkuseikoista, jotka muodostavat joiun taustan, ei ymmärrä joiun sisältöä ilman selvityksiä ja kommentteja.

Tämä katsaus joikujen kuvakieleen nojautuu pääpiirteissään Kiestingin ja Pistojärven perinneaineistoon. Uhtuan joikuperinteen piilokieli on jossain määrin suppeampaa, vaikka niissäkin on havaittavissa samanlaisia kielellisiä ilmiöitä ja kuvakielen erikoispiirteitä.

Karjalaisille joiuille kuten myöskin karjalaisille kansanrunoille on ominaista pitkälle kehittynyt kerto ja alkusointu. Seuraavassa on esimerkki Uhtuan joikualueelta:

Ei ole latnoi laulukieli, eikä šoma šsoittokieli;

En osua pajojani palmikoija, enkä soittojani solmiella...

Vielä esimerkki samalta joikujalta, Uljana Hoikalta:

En ole kuvuallini kukkujaini, enkä ole muasteri matkalaini, kun en voi kirjutella kelketyksie

Sekä kerto että alkusointu tämäntyylisessä joiussa ovat samankaltaista kuin kalevalamittaisessa runoudessa.

Vähän toiseen tapaan ilmenevät kerto ja alkusointu Kiestingin joikuperinteessä, jossa ne lähentelevät itkuvirsille luonteenomaisia tyylipiirteitä. Seuraaavassa on ote Hekla Arhipovan joiusta:

Anna kakši-kolmi šanua kovoriksentelen

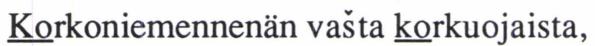
$\underline{\text { kun }}$ on kuklani kuva myöten omalla kotiniemellä.

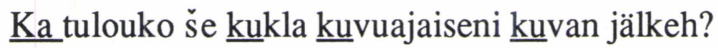

heeh joo hoo hoo hoo hoo hee ... (refrengi)

Heittelen kakši-kolmi... /ei, jo sevoin.../.

$\mathrm{Ni}$ virkkelen Vil'l'oiniemennenän vihhantavartta,

kuin šuoriou vierettelömäh veššelyä aikua Vill'l'oniemen tyvelläkä...

Tulouko še hot ... vieron jälkeh veršojaiseš

ta vielä viekkahan hyväsen?

hee hee hee hee eee joon ne ..... (refrengi)

(Fon. 213/17). 
Tämä joiku on hyvin tyypillinen sekä rakenteeltaan, kielenkäytöltään että tyyliltään. Sen alkusanat esiintyvät usein juuri tässä muodossa. Joiun säerakenne ja säejako ovat tälle perinteelle tyypillisiä. Epämääräisine säkeineen ja säestöineen ne myös muistuttavat itkuvirsiä. Seuraava katkelma sisältää kaksi saman ajatuksen sisältävää säkeistöä: joikuja laulaa Korkoniemen kärjessä kasvanutta nuorta miestä, jolla on omalla kotiniemellä mieleinen morsian; poikaa askarruttaa miellyttäneekö se "kukla" /nukke/ (- morsian) pojan äitiä?

Sama ajatus toistuu seuraavassakin säkeistössä: Laulan /kerron Vil'l'oiniemell'ä kasvanutta nuorta poikaa, joka aikoo menettää iloaikansa oman niemen tyvell'ä; miellyttäneekö /morsian/ hänen äitiänsä ja isäänsä?

Ensimmäisessä säeryhmässä alkusointu $k a-, k o-, k u$ - toistuu 13 kertaa (yhteinen sanamäärä on 22). Seuraavassa säkeistössä alkusointu vaihtuu, nyt alkutavuna ovat vi-, ve-, vie-, ja sillä alkaa 11 sanaa 22:sta. Näin ollen joiuissa kuten itkuvirsissäkin joka toinen säkeistöön kuluva sana on alkusoinnullinen. Alkusointu vaihtuu jokaisessa säeryhmässä, oli niitä kuinka monta tahansa.

Näytteistä näkyy, miten alkusointu ikäänkuin "määrittelee" kuvakielen komponenttien valikointia. Kun joikuja alussa käyttää verbiä kovoriksentelen /kerron, sanelen/ se vaikuttaa pojan kierto- t. piilonimityksen valintaan - korkuojaini; paikannimikin on Korkoniemennenän. Ikäänkuin langan päästä vetäen muodostuu tietty sanarykelmä.

Seuraavan säkeistön alkava verbi - virkkelen - antaa suunnan sen alkusoinnulle, ja joikuja sen mukaisesti valitsee muistivarastostaan vastaavat kuvakeinot; Vill'l'oniemen vihantavarsi, -poika, veršojaiseš - äiti, viekkahan hyväsen - isä.

Hekla Arhipovan joiussa toistuu säännöllisesti myös refrengi. Se seuraa jokaista säeryhmää tai runolausetta. Kaikkiaan tässä joiussa on 6 säkeistöä.

Myös kalevalamittaisissa joiuissa alkusointu vaikuttaa kielikeinojen va-

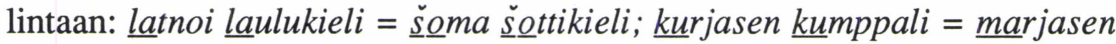

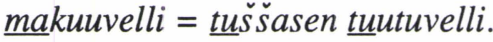

Joikuperinteen kielikeinot sekä tyylin erikoisuudet ovat hyvin monipuolisia, pitkälle kehittyneitä, ja siksi joiku onkin hienoa runoutta, monivivahteisine ja korkeatasoisine runokielineen. Tässäkin suhteessa voi yhtyä Arvo Launiksen arvioon, että joiku on "muinaisaikojen joutsenlaulua". 


\section{Kirjallisuutta ja lähteitä}

Anon.

1968 Karjalan kielen sanakirja. I osa Helsinki.

Anon.

1989 Pesennij fol'klor kesten'gskih karel (Kiestingin kansanlauluja). Izdanije pdgotovilla N.A.Lavonen. Petrozavodsk.

Itkonen E.

1963 "Lappalainen kansanrunous". Suomen kirjallisuus. I osa. Kirjoittamaton kirjallisuus. Keuruu.

Kuusi M.

1967 "Kalevalainen kertomarunous". Perinnetietoa. Toimit. Vuorela T. Tietolipas 52. Helsinki.

1963 "Varhaiskalevalainen runous". Suomen kirjallisuus. I osa. Kirjoittamaton kirjallisuus. Keuruu.

Lavonen N.

1987 "Osobennosti bitovanija joigi u kesten'gskih karel". XVII. Vsesojuznaja finno-ugorskaja konferentsija. Tezisi dokladov. T. 2. Ustinov.

Stepanova A., Koski T.

1977 "Karelskije joigi". Muzikal'noije nasledije finno-ugorskih narodov. Sost. i redaktoe I. Rüütel. Tallinn.

1983 "Karjalaisia joikuja". Punalippu n:o 8.

Väisänen A. O.

1915 "Vienan Karjalan kylissä". Uusi Suometar 3. (Myös Kansanmusiikki 1, 1985).

1917 "Vienan Karjalan joiuista". Aika 2.

1917 "Muistelmia". Kalevalaseuran vuosikirja 50.

1918 Vienan Karjalan joiut. Julkaisematon käsikirjoitus. SKS:n arkisto.

1990 Hiljainen haltioituminen. A.O. Väisäsen tutkielmia kansanmusiikista. Toim. Pekkilä E. Helsinki. 